\title{
SYNTHESIS OF 3-AMINO-7-ARYL-8-AZACHROMANS: VALIDATION OF A SYNTHETIC ROUTE WITH ENANTIOSELECTIVE POTENTIAL
}

\author{
EDUARD BADARAU ${ }^{\mathrm{a}, \mathrm{b}, \mathrm{c}}$, FRANCK SUZENET ${ }^{\mathrm{b}}$, \\ ADRIANA-LUMINITA FINARUc ${ }^{c}$ AND GERALD GUILLAUMET ${ }^{\mathrm{b},{ }^{*}}$
}

\begin{abstract}
A potential enantioselective access to 3-amino-7-aryl-8azachromans is described. The reported multi-step synthesis involved the use of aspartic acid as the building block that could induce chirality. The azachroman scaffold was obtained via a key intramolecular inverse DielsAlder cycloaddition between a 1,2,4-triazine and a judiciously functionalized alkyne. This class of compounds are hetero-isosteres of previously reported ligands of the histaminergic $\mathrm{H}_{3}$ receptor.
\end{abstract}

Keywords: 8-azachroman, inverse Diels-Alder cycloaddition, $H_{3} R$ ligands

\section{INTRODUCTION}

Inspired by their naturally occurring benzene analogues, the azachromans constitute a class of compounds of high interest in medicinal chemistry. Their interaction with the biological targets have the advantage of generating additional strong interactions (e.g. hydrogen bonding) compared to their benzene analogues, which finally translates to better biological activities. From a chemical point of view, the " $\mathrm{CH}$ " to "N" isosterism induce regioselectivity patterns, which allows a better control on the pharmacomodulation output.

a University of Bordeaux, Institute of Chemistry \& Biology of Membranes \& Nano-objects (CBMN), Allée Geoffroy Saint Hilaire, Bat B14, 33600, Pessac, France

b Institut de Chimie Organique et Analytique, Université d'Orléans, UMR-CNRS 6005, UFR Sciences, BP 6759, Rue de Chartres, 45067 Orléans Cedex 2, France

c Centrul de Cercetare "Chimie Aplicata si Inginerie de Proces", Universitatea din Bacau, Calea Marasesti, nr. 157, 600115 Bacau, Romania

*Corresponding author: gerald.guillaumet@univ-orleans.fr 
One of the medicinal chemistry projects developed by our group focuses on the lastly discovered serotoninergic receptor: $5-\mathrm{HT}_{7} \mathrm{R}$. Among the different series of compounds that we designed and synthesized as serotoninergic ligands, 8-azachromans was a class of compounds we developed using a Diels-Alder cycloaddition strategy. We already described in the past the synthesis of 8-azachromans [1], decorated on the oxane ring with an amine moiety, while the pyridine incorporated an aliphatic or aromatic substituent in the 7-position. Unfortunately, compared to the 8-substituted chromans, which were described as highly potent serotoninergic $5-\mathrm{HT}_{7}$ ligands [2], the 7-substituted-azachromans did not show a promising binding to the same receptors, most probably because of the shape mismatch between the reference and the newly synthesized molecules.

However, 7-arylchromans were reported as bioactive molecules for another CNS-involved target: the histaminergic $\mathrm{H}_{3}$ receptor $\left(\mathrm{H}_{3} \mathrm{R}\right)$ [3]. Because of the perfect 2D and shape similarity between the reported $\mathrm{H}_{3}$ antagonist and our series of azachromans (Scheme 1), we continued investigating this class of compounds. We were particularly interested in developing an enantioselective access to the 3-amino-7-aryl-8-azachromans.<smiles>[R16]C1COc2cc([Te])ccc2C1</smiles>

previously reported $\mathrm{H} 3 \mathrm{R}$ ligand

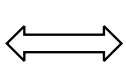

new hetero-isosteric analogues<smiles>[R16]C1COc2nc([Al])ccc2C1</smiles>

$\mathrm{Ar}^{2}$

\section{Scheme 1}

The synthesis of the desired isosters was designed on an intramolecular Diels-Alder cycloaddition approach between a 1,2,4-triazine (as electron-poor diene partner) and a terminal alkyne (as electron-rich dienophile partner). We validated in the past this inverse-electron demand DielsAlder methodology [1], however, in the case of 8-aza-3-aminochromans, our previous strategy involved a fast access to the desired molecules without chiral discrimination on the $\mathrm{C}_{3}$ center. As a next step of our research program, we were interested in developing a synthetic route with an enantioselectivity potential. Because of the optimization phase required by such a multistep synthesis (which should be devoided of any racemization steps), racemic starting materials were used, and, when all the synthetic issues would be solved, enantiopure starting materials could be used instead. The present paper exposes only the first validation step of the designed synthetic route and was conducted on racemic mixtures. 
The retrosynthetic plan was constructed on a key Diels-Alder cycloaddition step: the desired compounds I would be obtained via an intramolecular [4+2] cycloaddition conducted on the triazines II. The acetylenic intermediate II would be synthesized from the alcohol III (after its activation, as a sulfonate for example). Finally, the intermediate III would be the result of the sulfone substitution from triazine IV by the alcohol intermediate $\mathbf{V}$ (Scheme 2).<smiles>[Y8]C1COc2nc([Al])ccc2C1</smiles>

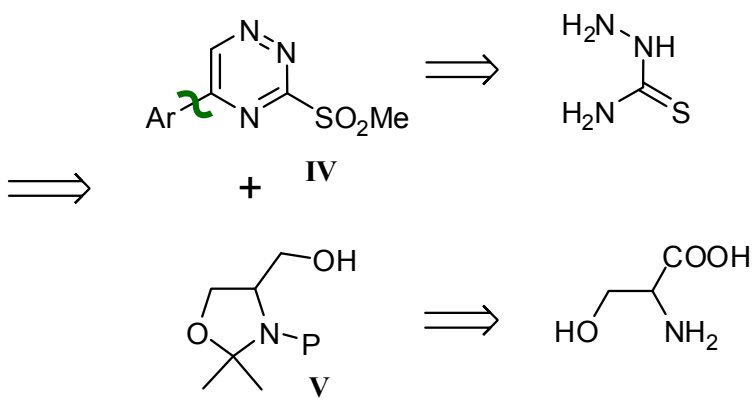

Scheme 2

\section{RESULTS AND DISCUSSION}

The synthesis started by obtaining the triazine intermediate 1 , using the previously published protocols [1], in 5 consecutive steps, starting from the commercially available thiosemicarbazide (Scheme 3).<smiles>NNC(N)=S</smiles>

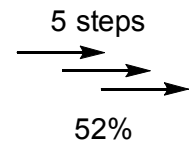<smiles>COc1cccc(OC)c1-c1cnnc(S(C)(=O)=O)n1</smiles>

Scheme 3

The alcohol $\mathbf{V}$ was obtained after 4 steps starting from $D, L-$ serine, and involved the synthesis originally described by Garner [4], with further improvements. Briefly, the starting amino-acid was reacted with di-tert-butyldicarbonate under basic conditions, and subsequently with iodomethane to 
give the ester 2 in $78 \%$ yield. Subsequently, the alcohol and the amine moieties were protected with an isopropylidene using dimethoxypropane and para-toluenesulfonic acid in refluxing toluene. The ester 3 was reduced to the corresponding alcohol 4 by lithium aluminum hydride in refluxing diethyl ether (Scheme 4).

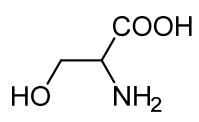

$D, L$ serine

(i) $\mathrm{Boc}_{2} \mathrm{O}, \mathrm{NaOH} 1 \mathrm{M}$

Dioxane

$12 \mathrm{~h}, 0^{\circ} \mathrm{C}-25^{\circ} \mathrm{C}$

(ii) $\mathrm{Mel}, \mathrm{K}_{2} \mathrm{CO}_{3}$

DMF $20 \mathrm{~h}, 0^{\circ} \mathrm{C}-25^{\circ} \mathrm{C}$

$78 \%$

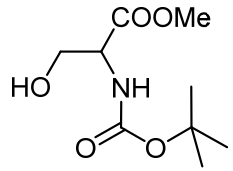

2

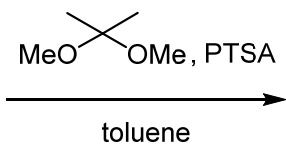

20h, reflux

$85 \%$<smiles>COC(=O)C1COC(C)(C)N1C(=O)OC(C)(C)C</smiles>

3

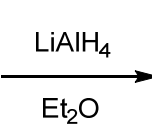

$1 \mathrm{~h}$, reflux

$70 \%$<smiles>CC(C)(C)OC(=O)N1C(CO)COC1(C)C</smiles>

4

Scheme 4

With both intermediates 1 and 4 available, the synthesis continued by sulfone substitution with the alkoxide 4 , followed by the isopropylidene cleavage under acidic conditions. The resultant alcohol 6 was subsequently activated as a methyl-sulfonate (7) and used for the next step as a crude product, because of its instability during the flash-chromatography purification step. (Scheme 5).

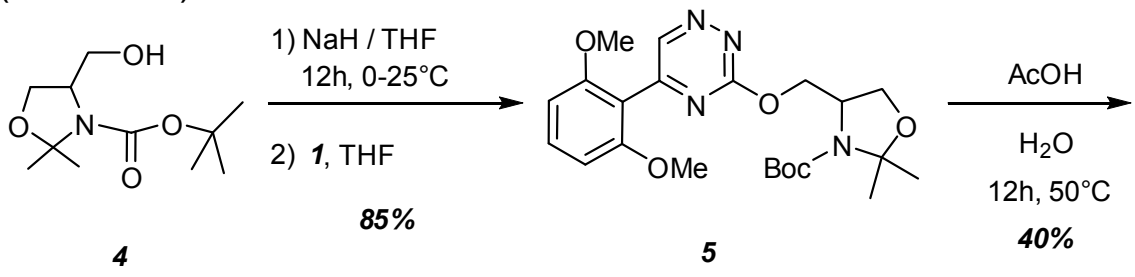<smiles>COc1cccc(OC)c1-c1cnnc(OCC(CO)NC(=O)OC(C)(C)C)n1</smiles>

6

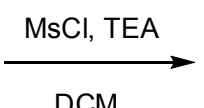

$12 \mathrm{~h}, 25^{\circ} \mathrm{C}$

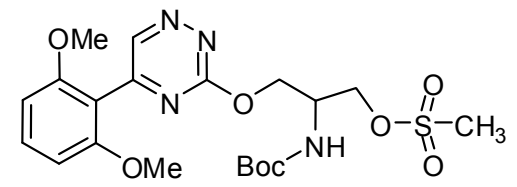

Scheme 5 
Several trials of substitution of the methylsulfonate (OMs) with different acetylene sources (phenyl or trimethylsilyl acetilydes) were unsuccessful, in all cases only the degradation of the starting material 7 was observed (Scheme 6). It should also be mentioned that the same synthetic strategy of activating the alcohol moiety as different sulfonates (methylsulfonate, para-toluenesulfonate or trifluoromethylsulfonate) was tested directly on the intermediate 4, but the subsequent substitution with various acetylides were also unsuccessful (results not presented).<smiles>COCC(COc1nncc(-c2c(OC)cccc2OC)n1)NC(=O)OCc1ccccc1</smiles><smiles>CC=NC</smiles><smiles>CC#CCC(COc1nncc(-c2c(OC)cccc2OC)n1)NC(=O)OCc1ccccc1</smiles>

Scheme 6

As the activated alcohol failed to deliver the desired alkyne, a backup strategy was subsequently used. Starting from the aspartic acid, we decided to generate the acetylene feature of the aminoalcohol VI, before its insertion on the triazinic intermediate IV (Scheme 7).<smiles>C#CCC(COc1nncc(Br)n1)NP</smiles><smiles>CO[Sb]([O])(=O)c1nncc(Br)n1</smiles><smiles>C=C</smiles><smiles>C#CC(CO)NP</smiles><smiles>C=CC(=O)CC(N)C(=O)O</smiles>

Scheme 7

The commercially available D,L-aspartic acid was submitted to a synthetic sequence following the protocols previously described in the literature $[5,6]$. The higher homologue of the Garner's aldehyde 8 was obtained with an excellent $43 \%$ yield, over 5 steps. Subsequently, the terminal alkyne could be generated via the 2-steps Corey-Fuchs method [7]: (i) reacting the aldehyde with triphenylphosphine and carbon tetrabromide conducted to the dibromoalkene intermediate 9 , and (ii) reacting 2 eq. of $n$-butyl lithium at low temperature generated, one-pot, a first bromide elimination step followed by a second halogen-metal exchange to conduct to the desired alkyne. Finally, the aminoacetal 10 was cleaved under acidic conditions and the amine moiety 
reprotected as the benzyl carbamate 11 (Scheme 8). The choice of the aromatic carbamate for the amine protection proved essential for the success of the Diels-Alder cycloaddition step (vide infra), contrarily to the thermally instable tert-butyl analogue.
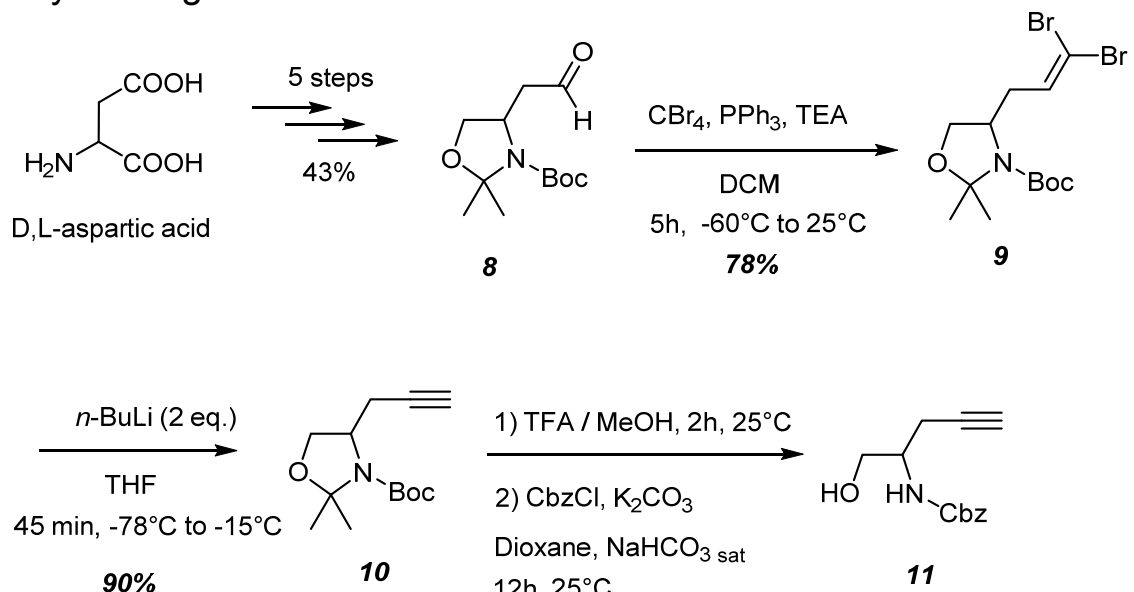

Dioxane, $\mathrm{NaHCO}_{3}$ sat

$12 \mathrm{~h}, 25^{\circ} \mathrm{C}$

11

$84 \%$

Scheme 8

Subsequently, the sulfone 1 was substituted by the alcoholate 11 to conduct to the desired Diels-Alder precursor 12 in good yield (88\%). This intermediate smoothly generated the [4+2] cycloadduct under microwaves irradiation at $220^{\circ} \mathrm{C}$. The carbamate was submitted to hydrogenolysis using a palladium catalyst. A final reductive amination step with formaldehyde conducted to the desired model compound 14 (Scheme 9).

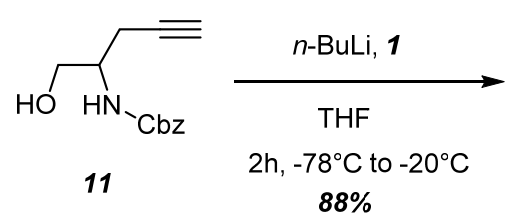<smiles>C#CCC(COc1nncc(-c2c(OC)cccc2OC)n1)NC(=O)OCc1ccccc1</smiles>

1) $\mathrm{MW} / \mathrm{PhCl}$ $1.5 \mathrm{~h}, 220^{\circ} \mathrm{C}$

2) $\mathrm{H}_{2}, \mathrm{Pd} / \mathrm{C}, \mathrm{HCl} 1 \mathrm{M}$ $\mathrm{EtOH}$ $3 \mathrm{~h}, 25^{\circ} \mathrm{C}$

$63 \%$<smiles>COc1cccc(OC)c1-c1ccc2c(n1)OCC(N)C2</smiles><smiles>COc1cccc(OC)c1-c1ccc2c(n1)OCC(N(C)C)C2</smiles>

Scheme 9 
SYNTHESIS OF 3-AMINO-7-ARYL-8-AZACHROMANS:

VALIDATION OF A SYNTHETIC ROUTE WITH ENANTIOSELECTIVE POTENTIAL

\section{CONCLUSIONS}

In conclusion, we present herein a general procedure for the synthesis of 3-amino-7-aryl-8-azachromans. This multi-step approach involved 12 linear steps, and was optimized to deliver the desired compounds in an overall $11 \%$ yield. One key step was particularly challenging: generation of the alkyne moiety. Our initial sulfonates substitutions assays by various acetylides proved unsuccessful. Unfortunately, no side-products could be isolated to explain a specific reactivity pattern. The back-up solution was to generate the alkyne moiety from an aldehyde precursor. The Corey-Fuchs method was successfully applied and allowed the synthesis of the key alkyne intermediate.

This synthetic route opens a window for subsequent SAR studies, as it allows modulations of the: (1) aryl substituent on the azachroman scaffold, (2) amine moiety and (3) potentially the C3 stereochemistry, by using enantiopure aspartic acid as starting material. Several pharmaco-modulations are currently investigated by our group with the final goal of identifying a new class of ligands targeting the histaminergic $\mathrm{H}_{3}$ receptor.

\section{EXPERIMENTAL SECTION}

${ }^{1} \mathrm{H}-\mathrm{NMR}$ and ${ }^{13} \mathrm{C}-\mathrm{NMR}$ were recorded with Bruker Avance DPX250 (250.131 MHz) and Bruker Avance II (400 MHz) spectrometers in CDCl3, using tetramethylsilane as an internal standard. Multiplicities were determined by the DEPT135 sequence; chemical shifts are reported in parts per million (ppm).

Coupling constants are reported in units of Hertz [Hz]. Infrared (IR) spectra were recorded with a Perkin-Elmer Paragon 1000 PC FTIR using $\mathrm{NaCl}$ films or $\mathrm{KBr}$ pellets. Low-resolution mass spectra (MS) were recorded with a Perkin-Elmer SCIEX AOI 300 spectrometer. High-resolution mass spectra were recorded with a Q-Tof micro Waters spectrometer. Melting points were determined in open capillary tubes and are uncorrected. Flash chromatography was performed on Merck 40-70 nM (230-400 mesh) silica gel under nitrogen pressure. Thin-layer chromatography (TLC) was carried out on Merck silica gel 60 F254 precoated plates. Visualization was made with ultraviolet light $(\lambda=254 \mathrm{~nm})$ and, if necessary, an ethanolic solution of potassium permanganate. Reactions requiring anhydrous conditions were performed under nitrogen. Toluene and tetrahydrofuran were freshly distilled from sodium / benzophenone under argon prior to use.

Methyl 2-[(tert-butoxycarbonyl)amino]-3-hydroxypropanoate (2). D,Lserine ( $35 \mathrm{~g}, 333.05 \mathrm{mmol}, 1 \mathrm{eq}$.) was disolved in sodium hydroxide (1M aq. soln. $666 \mathrm{~mL}, 666.10 \mathrm{mmol}, 2$ eq.) and dioxane $(340 \mathrm{~mL})$. The mixture was cooled to $0^{\circ} \mathrm{C}$ and di-tert-butyldicarbonate was subsequently added $(87 \mathrm{~g}$, 
$399.66 \mathrm{mmol}, 1.2 \mathrm{eq}$.). The mixture was stirred for $12 \mathrm{~h}$ at room temperature. During the reaction time, the $\mathrm{pH}$ was corrected to $9-10$ by addition of sodium hydroxide (1M aq.soln.). The organic solvent was evaporated and the aqueous phase was washed with diethyl ether to remove unreacted di-tertbutyldicarbonate. Then, the $\mathrm{pH}$ of the recovered aqueous phase was adjusted to 2-3 by addition of sulfuric acid (1M aq. soln.), before extraction of organic materials with ethyl acetate $(3 \times 400 \mathrm{~mL})$. The combined organic layers were dried over magnesium sulfate, filtered and the solvent was removed under vacuum to give the crude carbamate as a viscous yellow oil. The obtained Boc-serine (44 g, $214.41 \mathrm{mmol}, 1$ eq.) was dissolved in $350 \mathrm{~mL}$ DMF and the mixture was cooled to $0^{\circ} \mathrm{C}$. Under nitrogen atmosphere, potassium carbonate $(32.60 \mathrm{~g}, 235.85 \mathrm{mmol}, 1.1 \mathrm{eq}$.) and methyl iodide (26.7 $\mathrm{ml}, 428.83 \mathrm{mmol}, 2$ eq.) were subsequently added. After $20 \mathrm{~h}$ of stirring at room temperature, the solvent was evaporated and the crude product was dissolved in ethyl acetate $(200 \mathrm{~mL})$ and washed with water and brine. The organic phase was dried over magnesium sulfate, filtered and the solvent was removed under vacuum to conduct to a yellow viscous oil, used as a crude product for the next step. Yield 78\%; ${ }^{1} \mathrm{H}-\mathrm{NMR}\left(\mathrm{CDCl}_{3}, 250 \mathrm{~Hz}\right): \delta$ (ppm) $1.39\left(\mathrm{~s}, 9 \mathrm{H}, 3 \mathrm{CH}_{3}\right), 3.35(\mathrm{ls}, 1 \mathrm{H}, \mathrm{OH}), 3.71\left(\mathrm{~s}, 3 \mathrm{H}, \mathrm{CH}_{3}\right), 3.78-3.92(\mathrm{~m}$, $\left.2 \mathrm{H}, \mathrm{CH}_{2} \mathrm{OH}\right), 4.7-4.49(\mathrm{~m}, 1 \mathrm{H}, \mathrm{CHNH}), 5.61(\mathrm{~d}, 1 \mathrm{H}, \mathrm{NH}, J=7.8 \mathrm{~Hz}) ;{ }^{13} \mathrm{C}-$ $\operatorname{NMR}\left(\mathrm{CDCl}_{3}, 62.9 \mathrm{~Hz}\right): \delta(\mathrm{ppm}) 28.3\left(\mathrm{CH}_{3}\right), 52.6\left(\mathrm{CH}_{3}\right), 55.8(\mathrm{CH}), 63.2$ $\left(\mathbf{C H}_{2}\right), 80.3\left(\mathbf{C}_{\mathrm{q}}\right), 155.9\left(\mathbf{C}_{\mathrm{q}}\right), 171.6\left(\mathbf{C}_{\mathrm{q}}\right)$; IR (ATR-Ge) : v $\left(\mathrm{cm}^{-1}\right)$ 3391, 2977, 1692, 1507, 1366, 1210, 1159, 1058, 1029; SM (ESI): $\mathrm{m} / \mathrm{z}=242.0[\mathrm{M}+\mathrm{Na}]^{+}$.

3-Tert-butyl 4-methyl 2,2-dimethyl-1,3-oxazolidine-3,4-dicarboxylate (3). Under inert atmosphere, 2,2-dimethoxypropane $(42.4 \mathrm{~mL}, 341.85 \mathrm{mmol}$, 2.5 eq.) and monohydrated para-toluenesulfonic acid $(0.52 \mathrm{~g}, 2.74 \mathrm{mmol}, 0.02$ eq.) were added to a solution of compound $2(30 \mathrm{~g}, 136.74 \mathrm{mmol}, 1 \mathrm{eq}$.) in 600 $\mathrm{mL}$ dry toluene. After $30 \mathrm{~min}$ of refluxing, $190 \mathrm{ml}$ of co-solvents were distilled using a Dean-Stark trap. A new portion of 2,2-dimethoxypropane $(17 \mathrm{~mL}, 138.74$ mmol, 1 eq.) and monohydrated PTSA (0.26 g $1.37 \mathrm{mmol}, 0.01$ eq.) were added, and the mixture was refluxed for 30 more minutes. Additional $190 \mathrm{~mL}$ of reaction mixture were distilled using a Dean-Stark trap and the remaining reaction mixture was refluxed for $20 \mathrm{~h}$. The volatiles were evaporated, the crude product was dissolved in ethyl acetate $(150 \mathrm{~mL})$ and washed with sodium bicarbonate (satd. aq. soln., $150 \mathrm{~mL}$ ). The organic materials were extracted from the aqueous phase with ethyl acetate $(2 \times 200 \mathrm{~mL})$. The combined organic layers were washed with brine, dried over magnesium sulfate and concentrated under vacuum. The crude product was purified by flash chromatography (PE/EtOAc 9/1) to conduct to the desired aminoacetal 3 as a light-yellow oil. Yield 85\%; Mixture of conformers (A/B $\sim 6 / 4$, as resulted from the integration of the two ${ }^{1} \mathrm{H}-\mathrm{NMR}$ signals corresponding to the $\mathrm{CH}_{3}$-C-NBoc substituents): ${ }^{1} \mathrm{H}-\mathrm{NMR}\left(\mathrm{CDCl}_{3}, 250 \mathrm{~Hz}\right): \delta(\mathrm{ppm}) 1.32(\mathrm{~s}, 5 \mathrm{H}), 1.41$ and $1.44(2 \mathrm{x} \mathrm{s}, 7 \mathrm{H}), 1.55$ and $1.57(2 \times \mathrm{s}, 3 \mathrm{H}), 3.66\left(\mathrm{~s}, 3 \mathrm{H}, \mathrm{CH}_{3}\right), 3.91-4.10\left(\mathrm{~m}, 2 \mathrm{H}, \mathrm{CH}_{2} \mathrm{O}\right), 4.27-4.41$ 
(m, 1H, CHNH). ${ }^{13} \mathrm{C}-\mathrm{NMR}\left(\mathrm{CDCl}_{3}, 62.9 \mathrm{~Hz}\right): \delta(\mathrm{ppm}) 24.3,24.9,25.1,26.0\left(\mathrm{CH}_{3}\right)$, $28.2\left(\mathrm{CH}_{3}\right), 28.3\left(\mathrm{CH}_{3}\right), 52.2\left(\mathrm{CH}_{3}\right), 52.3\left(\mathrm{CH}_{3}\right), 59.2(\mathrm{CH}), 59.2(\mathrm{CH}), 66.0$ $\left(\mathbf{C H}_{2}\right), 66.2\left(\mathbf{C H}_{2}\right), 80.2\left(\mathbf{C}_{\mathrm{q}}\right), 80.8\left(\mathbf{C}_{\mathrm{q}}\right), 94.3\left(\mathbf{C}_{\mathrm{q}}\right), 95.0\left(\mathbf{C}_{\mathrm{q}}\right), 151.1\left(\mathbf{C}_{\mathrm{q}}\right), 152.0$ $\left(\mathbf{C}_{\mathrm{q}}\right), 171.2\left(\mathbf{C}_{\mathrm{q}}\right), 171.6\left(\mathbf{C}_{\mathrm{q}}\right)$; IR (ATR-Ge): v $\left(\mathrm{cm}^{-1}\right)$ 2976, 1762, 1711, 1393, 1255, 1199, 1168; SM (ESI): $m / z=282.0[\mathrm{M}+\mathrm{Na}]^{+}$.

Tert-butyl 4-(hydroxymethyl)-2,2-dimethyl-1,3-oxazolidine-3-carboxylate (4). In a $100 \mathrm{~mL}$ round bottom flask, under inert atmosphere, a solution of the previously purified ester $3(3 \mathrm{~g}, 11.58 \mathrm{mmol}, 1 \mathrm{eq}$.) in dry diethyl ether (30 $\mathrm{mL}$ ) was added to a suspension of lithium aluminum hydride $(0.44 \mathrm{~g}, 11.58$ mmol, 1 eq.) in dry diethyl ether $(30 \mathrm{~mL})$. The mixture was refluxed for $1 \mathrm{~h}$, and subsequently cooled to room temperature. The excess of hydride was hydrolyzed by slow successive addition of water $(0.44 \mathrm{~mL})$, sodium hydroxide (15\% aq. soln., $0.44 \mathrm{~mL})$ and finally water $(1.32 \mathrm{~mL})$. The precipitate was filtered on a Celite pad and was washed with diethyl ether. The filtrate was dried over magnesium sulfate, filtered and concentrated under vacuum. The crude product was purified by flash-chromatography PE/EtOAc 7/3) to give the desired alcohol 4. Yield: $70 \%$; ${ }^{1} \mathrm{H}-\mathrm{NMR}\left(\mathrm{CDCl}_{3}, 250 \mathrm{~Hz}\right): \delta(\mathrm{ppm}) 1.42$ (as, $\left.12 \mathrm{H}, 4 \mathrm{CH}_{3}\right), 1.48\left(\mathrm{~s}, 3 \mathrm{H}, \mathrm{CH}_{3}\right), 3.49-3.93\left(\mathrm{~m}, 5 \mathrm{H}, \mathrm{CHNH}, \mathrm{CH}_{2} \mathrm{O}, \mathrm{CH}_{2} \mathrm{OH}\right.$ ); ${ }^{13} \mathrm{C}-\mathrm{NMR}\left(\mathrm{CDCl}_{3}, 62.9 \mathrm{~Hz}\right): \delta(\mathrm{ppm}) 24.5,27.2\left(2 \mathrm{CH}_{3}\right), 28.4\left(3 \mathrm{CH}_{3}\right), 59.4$ $(\mathbf{C H}), 64.4,65.3\left(2 \mathrm{CH}_{2}\right), 81.1\left(\mathbf{C}_{\mathrm{q}}\right), 94.0\left(\mathbf{C}_{\mathrm{q}}\right), 153.8\left(\mathbf{C}_{\mathrm{q}}\right)$; IR (ATR-Ge): v $\left(\mathrm{cm}^{-1}\right)$ 3458, 2983, 1665, 1401, 1365, 1247, 1072, 1102, 1048, 885; MS (ESI) : m/z $=232.0[\mathrm{M}+\mathrm{H}]^{+}, 254[\mathrm{M}+\mathrm{Na}]^{+}$.

Tert-butyl-4-[[5-(2,6-dimethoxyphenyl)-1,2,4-triazin-3-yl]oxymethyl]2,2-di-methyl-oxa-zolidine-3-carboxylate (5). Under nitrogen atmo-sphere, a solution of the alcohol $4(3.30 \mathrm{~g}, 14.22 \mathrm{mmol}, 1.2 \mathrm{eq}$.) in dry THF $(10 \mathrm{~mL})$ was added to a suspension of sodium hydride $(60 \%$ dispersion in mineral oil, 0.57 $\mathrm{g}, 14.22 \mathrm{mmol}, 1.2$ eq.) in dry $\operatorname{THF}(80 \mathrm{~mL})$. After $30 \mathrm{~min}$ of stirring at $0^{\circ} \mathrm{C}$, a solution of sulfone 1 ( $3.5 \mathrm{~g}, 11.85 \mathrm{mmol}, 1$ eq.) in dry THF $(30 \mathrm{~mL})$ was added dropwise. The reaction mixture was allowed to come back to room temperature overnight under stirring, and subsequently quenched by addition of water (100 $\mathrm{mL})$. The organics were extracted with dichloromethane $(3 \times 100 \mathrm{~mL})$. The combined organic layers were dried over magnesium sulfate, filtered and the solvent was evaporated under reduced pressure. The crude product was purified by flash chromatography (PE/EtOAc 6/4) to give the desired compound $\mathbf{5}$ as a yellow oil. Yield: $85 \%$; ${ }^{1} \mathrm{H}-\mathrm{NMR}\left(\mathrm{CDCl}_{3}, 250 \mathrm{~Hz}\right): \delta(\mathrm{ppm}) 1.41-1.58(\mathrm{~m}, 15 \mathrm{H}$, $\left.5 \mathrm{CH}_{3}\right), 3.71\left(\mathrm{~s}, 6 \mathrm{H}, 2 \mathrm{CH}_{3}\right), 3.96-4.00(\mathrm{~m}, 1 \mathrm{H}), 4.11-4.15(\mathrm{~m}, 1 \mathrm{H}), 4.32-4.39(\mathrm{~m}$, $2 \mathrm{H}), 4.64-4.76\left(\mathrm{~m}, 1 \mathrm{H}, \mathrm{CH}_{2} \mathrm{OC}=\mathrm{N}\right), 6.60(\mathrm{~d}, 2 \mathrm{H}, 2 \mathrm{CH}, J=8.0 \mathrm{~Hz}), 7.35(\mathrm{t}, 1 \mathrm{H}$, $\mathrm{CH}, J=8.0 \mathrm{~Hz}$ ), $8.89(\mathrm{~s}, 1 \mathrm{H}, \mathrm{CH}) ;{ }^{13} \mathrm{C}-\mathrm{NMR}\left(\mathrm{DMSO}, 62.9 \mathrm{~Hz}, 80^{\circ} \mathrm{C}\right): \delta(\mathrm{ppm})$ $26.2\left(\mathrm{CH}_{3}\right), 27.6\left(3 \mathrm{CH}_{3}\right), 30.0\left(\mathrm{CH}_{3}\right), 55.1(\mathrm{CH}), 55.8\left(\mathrm{CH}_{3} \mathrm{O}\right), 64.5\left(\mathrm{CH}_{2} \mathrm{O}\right)$, $66.3\left(\mathrm{CH}_{2} \mathrm{O}\right), 79.1\left(\mathbf{C}_{\mathrm{q}}\right), 93.0\left(\mathbf{C}_{\mathrm{q}}\right), 104.6(2 \mathrm{CH}), 112.3\left(\mathbf{C}_{\mathrm{q}}\right), 131.9(\mathbf{C H}), 146.7$ $(\mathbf{C H}), 150.9\left(\mathbf{C}_{\mathrm{q}}\right), 157.2\left(\mathbf{C}_{\mathrm{q}}\right), 157.6\left(\mathbf{C}_{\mathrm{q}}\right), 164.7\left(\mathbf{C}_{\mathrm{q}}\right) ; \mathrm{IR}(\mathrm{NaCl}): \mathrm{V}\left(\mathrm{cm}^{-1}\right)$ 2977, 1692, 1598, 1472, 1364, 1251, 1169, 1107, 1085, 1021, 730; MS (ESI) $: \mathrm{m} / \mathrm{z}=$ $447.5[\mathrm{M}+\mathrm{H}]^{+}$. 
Tert-butyl N-[1-[[5-(2,6-dimethoxyphenyl)-1,2,4-triazin-3-yl]oxymethyl]-2hydroxy-ethyl]carba-mate (6). The previously obtained compound 5 (3 g, 6.719 $\mathrm{mmol}, 1$ eq.) was added to an acetic acid/water mixture $(60 \mathrm{~mL} / 15 \mathrm{~mL})$ and the reaction was stirred for $12 \mathrm{~h}$ at $50^{\circ} \mathrm{C}$. The solvents were subsequently co-evaporated with toluene, the residue was diluted with water $(50 \mathrm{~mL})$ and was extracted with ethyl acetate $(3 \times 50 \mathrm{~mL})$. The combined organic layers were dried oved magnesium sulfate, filtered and the solvent was evaporated under vacuum to conduct to the desired aminoalcohol $\mathbf{6}$ as a highly viscous yellow oil. Yield: $40 \%$; ${ }^{1} \mathrm{H}-\mathrm{NMR}\left(\mathrm{CDCl}_{3}, 250 \mathrm{~Hz}\right)$ : $\delta(\mathrm{ppm}) 1.41\left(\mathrm{~s}, 9 \mathrm{H}, 3 \mathrm{CH}_{3}\right)$, 3.69-3.87 $\left(\mathrm{m}, 8 \mathrm{H}, 2 \mathrm{CH}_{3} \mathrm{O}, \mathrm{CH}_{2} \mathrm{OH}\right), 4.03-4.10(\mathrm{~m}, 1 \mathrm{H}, \mathrm{CHNH}), 4.58-4.77$ $\left(\mathrm{m}, 2 \mathrm{H}, \mathrm{CH}_{2} \mathrm{OC}=\mathrm{N}\right), 5.31(\mathrm{~d}, 1 \mathrm{H}, \mathrm{NH}, J=7.5 \mathrm{~Hz}), 6.63(\mathrm{~d}, 2 \mathrm{H}, 2 \mathrm{CH}, J=$ $8.3 \mathrm{~Hz}), 7.39(\mathrm{t}, 1 \mathrm{H}, \mathrm{CH}, \mathrm{J}=8.3 \mathrm{~Hz}), 8.94(\mathrm{~s}, 1 \mathrm{H}, \mathrm{CH}) .{ }^{13} \mathrm{C}-\mathrm{NMR}\left(\mathrm{CDCl}_{3}, 62.9\right.$ $\mathrm{Hz}): \delta(\mathrm{ppm}) 28.5\left(3 \mathrm{CH}_{3}\right), 51.5(\mathrm{CH}), 56.0\left(2 \mathrm{CH}_{3} \mathrm{O}\right), 61.8\left(\mathrm{CH}_{2}\right), 67.0$ $\left(\mathrm{CH}_{2} \mathrm{OC}=\mathrm{N}\right), 79.9\left(\mathbf{C}_{\mathrm{q}}\right), 104.2(2 \mathrm{CH}), 112.2\left(\mathbf{C}_{\mathrm{q}}\right), 132.6(\mathbf{C H}), 147.7(\mathbf{C H})$, $155.9\left(\mathbf{C}_{\mathrm{q}}\right), 158.3\left(\mathbf{C}_{\mathrm{q}}\right), 165.3\left(\mathbf{C}_{\mathrm{q}}\right)$; IR $(\mathrm{NaCl}): \mathrm{v}\left(\mathrm{cm}^{-1}\right) 3432,2984,1697,1600$, 1514, 1255, 1110, 1022, 755; MS (ESI): $\mathrm{m} / \mathrm{z}=407.5[\mathrm{M}+\mathrm{H}]^{+}$.

[2-(Tert-butoxycarbonylamino)-3-[[5-(2,6-dimethoxyphenyl)-1,2,4-triazin3-yl]oxy]propyl] methanesulfonate (7). Under inert atmosphere, methane-sulfonyl chloride $(0.05 \mathrm{~mL}, 0.59 \mathrm{mmol}, 1.2$ eq. $)$ was added to a solution of alcohol 6 $(0.2 \mathrm{~g}, 0.49 \mathrm{mmol}, 1$ eq.) and triethylamine $(0.08 \mathrm{~mL}, 0.59 \mathrm{mmol}, 1.2$ eq. $)$ in dry DCM $(5 \mathrm{~mL})$. The mixture was stirred for $12 \mathrm{~h}$ at room temperature, and after complete consumption of the starting material, the reaction was quenched by addition of water $(20 \mathrm{~mL})$. The organics were extracted with ethyl acetate $(3 \times 30 \mathrm{~mL})$, the combined organic layers were dried over magnesium sulfate, filtered and the solvent was evaporated under reduced pressure. The obtained moisture-sensitive product was subsequently used without further purification. ${ }^{1} \mathrm{H}-\mathrm{NMR}\left(\mathrm{CDCl}_{3}, 250 \mathrm{~Hz}\right): \delta(\mathrm{ppm}) 1.451\left(\mathrm{~s}, 9 \mathrm{H}, 3 \mathrm{CH}_{3}\right), 3.04\left(\mathrm{~s}, 3 \mathrm{H}, \mathrm{CH}_{3} \mathrm{~S}\right)$, $3.79\left(\mathrm{~s}, 6 \mathrm{H}, 2 \mathrm{CH}_{3} \mathrm{O}\right), 4.36-4.48(\mathrm{~m}, 1 \mathrm{H}, \mathrm{CHNH}), 4.57-4.59\left(\mathrm{~m}, 2 \mathrm{H}, \mathrm{CH}_{2} \mathrm{OS}\right)$, 4.61-4.68 (m, 2H, $\left.\mathrm{CH}_{2} \mathrm{OC}=\mathrm{N}\right), 6.63(\mathrm{~d}, 2 \mathrm{H}, 2 \mathrm{CH}, J=8.3 \mathrm{~Hz}), 7.43(\mathrm{t}, 1 \mathrm{H}, \mathrm{CH}$, $J=8.3 \mathrm{~Hz}), 8.99(\mathrm{~s}, 1 \mathrm{H}, \mathrm{CH}) ;{ }^{13} \mathrm{C}-\mathrm{NMR}\left(\mathrm{CDCl}_{3}, 62.9 \mathrm{~Hz}\right): \delta(\mathrm{ppm}) 28.4$ $\left(3 \mathrm{CH}_{3}\right), 37.5\left(\mathrm{CH}_{3} \mathrm{~S}\right), 48.8(\mathrm{CH}), 56.2\left(2 \mathrm{CH}_{3} \mathrm{O}\right), 66.8\left(\mathrm{CH}_{2} \mathrm{OS}\right), 67.7$ $\left(\mathrm{CH}_{2} \mathrm{OC}=\mathrm{N}\right), 80.4\left(\mathrm{C}_{\mathrm{q}}\right), 104.3(2 \mathrm{CH}), 112.0\left(\mathrm{C}_{\mathrm{q}}\right), 133.2(\mathrm{CH}), 147.7(\mathrm{CH})$, $155.7\left(\mathrm{C}_{\mathrm{q}}\right), 158.6\left(\mathrm{C}_{\mathrm{q}}\right), 165.5\left(\mathrm{C}_{\mathrm{q}}\right)$.

Tert-butyl 4-(3,3-dibromoallyl)-2,2-dimethyl-oxazolidine-3-carboxylate (9). Under inert atmosphere, a solution of carbon tetrabromide $(17.45 \mathrm{~g}, 52.61$ $\mathrm{mmol}, 3.2$ eq.) in dry $\mathrm{DCM}(50 \mathrm{~mL})$ was added at $-40^{\circ} \mathrm{C}$ to a solution of triphenylphosphine $(27.60 \mathrm{~g}, 105.22 \mathrm{mmol}, 6.4$ eq.) in dry DCM $(400 \mathrm{~mL})$. After 15 min of vigorous stirring at low temperature, dry trimethylamine was subsequently added $(28.6 \mathrm{~mL}, 205.5 \mathrm{mmol}, 12.5 \mathrm{eq}$.) and the mixture was cooled to $-78^{\circ} \mathrm{C}$ before adding a solution of aldehyde $8(4 \mathrm{~g}, 16.44 \mathrm{mmol}, 1 \mathrm{eq}$.), synthesized as previously described in the literature)[5] in dry DCM $(50 \mathrm{~mL})$. After 10 min of stirring at $-78^{\circ} \mathrm{C}$, the reaction was continued for $2 \mathrm{~h}$ at $0^{\circ} \mathrm{C}$. 
After the complete consumption of the starting material, the reaction was quenched by addition of water $(150 \mathrm{~mL})$ and hydrogen peroxide $(30 \%$ aq. soln., $40 \mathrm{~mL}$ ) and further stirring for $20 \mathrm{~min}$ at room temperature. Subsequently, the organic layer was separated, and the remaining organic materials from the water phase were further extracted with DCM $(2 \times 200 \mathrm{~mL})$. The combined organic layers were dried over magnesium sulfate, filtered and the solvent was evaporated under reduced pressure. The crude product was purified by flashchromatography (PE / EtOAc 8/2) to give a white solid. Yield $78 \%$; ${ }^{1} \mathrm{H}-\mathrm{NMR}$ $\left(\mathrm{CDCl}_{3}, 250 \mathrm{~Hz}\right)(1 / 1$ mixture of two conformers): $\delta(\mathrm{ppm}) 1.43-1.59(\mathrm{~m}, 15 \mathrm{H}$, $\left.5 \mathrm{CH}_{3}\right), 2.40-2.49\left(\mathrm{~m}, 2 \mathrm{H}, \mathrm{CH}_{2} \mathrm{C}=\mathrm{C}\right), 3.71\left(\mathrm{~d}, 1 \mathrm{H}, \mathrm{CH}_{2} \mathrm{O}, J=8.0 \mathrm{~Hz}\right), 3.90-$ $4.05(\mathrm{~m}, 2 \mathrm{H}, \mathrm{CHN}), 6.38-6.45(\mathrm{~m}, 1 \mathrm{H}, \mathrm{CH}=\mathrm{C}) ;{ }^{13} \mathrm{C}-\mathrm{NMR}\left(\mathrm{CDCl}_{3}, 62.9 \mathrm{~Hz}\right)$ (1/1 mixture of two conformers): $\delta$ (ppm) 23.2, $24.5\left(\mathrm{CH}_{3}\right), 26.8,27.5\left(\mathrm{CH}_{3}\right)$, 28.5, $28.6\left(3 \mathrm{CH}_{3}\right), 36.6,37.4\left(\mathrm{CH}_{2} \mathrm{C}=\mathrm{C}\right), 55.6,55.9(\mathrm{CHN}), 66.7,67.1\left(\mathrm{CH}_{2} \mathrm{O}\right)$, 80.1, 80.5 $\left(\mathbf{C}_{\mathrm{q}}\right), 91.0\left(\mathbf{C}_{\mathrm{q}} \mathrm{Br}\right)$, 93.8, $94.4\left(\mathbf{C}_{\mathrm{q}} \mathrm{N}\right)$, 134.8, $135.0(\mathbf{C H}=\mathrm{C})$, 151.7, $152.3\left(\mathbf{C}_{\mathrm{q}}\right)$; IR (ATR-Ge): v $\left(\mathrm{cm}^{-1}\right)$ 2971, 1685, 1396, 1383, 1086; MS (ESI): $\mathrm{m} / \mathrm{z}=420.0[\mathrm{M}+\mathrm{Na}]^{+}, 422.0[\mathrm{M}+\mathrm{Na}]^{+}, 424[\mathrm{M}+\mathrm{Na}]^{+}$; Melting point: $96-98^{\circ} \mathrm{C}$.

Tert-butyl 2,2-dimethyl-4-prop-2-ynyl-oxazolidine-3-carboxylate (10). $n$-butyl lithium (2.1 M in THF, $10 \mathrm{~mL}, 21.05 \mathrm{mmol}, 2.1$ eq.) was added at $-78^{\circ} \mathrm{C}$ to a solution of the previously isolated dibromide $9(4 \mathrm{~g}, 10.02 \mathrm{mmol}$, 1 eq.) in dry THF $(100 \mathrm{~mL})$. After 40 min of stirring at $-78^{\circ} \mathrm{C}$, the bath temperature was adjusted to $-15^{\circ} \mathrm{C}$ and the mixture was stirred 15 additional minutes. The reaction was subsequently quenched by addition of sodium hydroxide $(0.01 \mathrm{M}$ aq. soln., $50 \mathrm{~mL})$. The organic materials were extracted with ethyl acetate $(3 \times 100 \mathrm{~mL})$, the combined organic layers were dried over magnesium sulfate and the solvent was evaporated under reduce pressure. The crude product was purified by flash-chromatography (DCM) to give the desired alkyne 10 as a colorless oil. Yield: $90 \%$; ${ }^{1} \mathrm{H}-\mathrm{NMR}\left(\mathrm{CDCl}_{3}, 250 \mathrm{~Hz}\right)$ : $\delta(\mathrm{ppm}) 1.44\left(\mathrm{~s}, 12 \mathrm{H}, 4 \mathrm{CH}_{3}\right), 1.51-1.55\left(\mathrm{~m}, 3 \mathrm{H}, \mathrm{CH}_{3}\right), 1.92-1.95(\mathrm{~m}, 1 \mathrm{H}, \mathrm{CH})$, 2.30-2.70 (m, 2H, CH $\left.\mathrm{CH}_{2} \mathrm{CHN}\right), 3.91-3.96\left(\mathrm{~m}, 3 \mathrm{H}, \mathrm{CH}_{2} \mathrm{O}, \mathrm{CHN}\right) ;{ }^{13} \mathrm{C}-\mathrm{NMR}$ $\left(\mathrm{CDCl}_{3}, 62.9 \mathrm{~Hz}\right): \delta(\mathrm{ppm})$ (two conformers) 22.3, $23.1\left(\mathrm{CH}_{2} \mathrm{CHN}\right), 23.4,24.6$ $\left(\mathrm{CH}_{3}\right), 26.8,27.6\left(\mathrm{CH}_{3}\right), 28.5\left(3 \mathrm{CH}_{3}\right), 56.4,56.6(\mathrm{CHN}), 66.5,66.7\left(\mathrm{CH}_{2} \mathrm{O}\right)$, 70.0, 70.2 (CH), 80.0, 80.4 ( $\left.\mathbf{C}_{\mathrm{q}}\right), 80.9,81.0\left(\mathbf{C}_{\mathrm{q}}\right), 93.8,94.4\left(\mathbf{C}_{\mathrm{q}}\right), 151.5,152.1$ $\left(\mathbf{C}_{\mathrm{q}}\right)$; IR (ATR-Ge): v $\left(\mathrm{cm}^{-1}\right)$ 3304, 2976, 2129, 1696, 1399, 1260, 1102; MS (ESI): $m / z=262.0[\mathrm{M}+\mathrm{Na}]^{+}$.

Benzyl N-[1-(hydroxymethyl)but-3-ynyl]carbamate (11). A solution of compound 10 ( $2 \mathrm{~g}, 10.04 \mathrm{mmol}, 1$ eq.) in methanol $(10 \mathrm{~mL})$ was added to trifluoroacetic acid $(40 \mathrm{~mL})$. After $2 \mathrm{~h}$ of reaction at room temperature, the solvents were co-evaporated (never to dryness !) with diethyl ether $(3 \times 50 \mathrm{~mL})$. Another co-evaporation with dioxane $(40 \mathrm{~mL})$ allowed removal of residual solvents. The crude product was dissolved in sodium bicarbonate (satd. aq. soln., $40 \mathrm{~mL}$ ) and the $\mathrm{pH}$ was corrected to 8 by addition of trace amounts of pure sodium bicarbonate. Potassium carbonate (1.8 g, $13.05 \mathrm{mmol}, 1.3 \mathrm{eq}$.) 
and benzyl chloroformate $(1.7 \mathrm{~mL}, 12.05 \mathrm{mmol}, 1.2$ eq.) were subsequently added, and the reaction mixture was stirred for $12 \mathrm{~h}$ at room temperature. After the complete consumption of the starting material, water was added (60 $\mathrm{mL})$ and the organics were extracted with ethyl acetate $(3 \times 100 \mathrm{~mL})$. The combined organic layers were dried over magnesium sulfate, filtered and the solvent was removed under vacuum. The crude product was purified by flash-chromatography (PE / EtOAc 5/5) to conduct to the desired carbamate 11, isolated as a white solid. Yield: $84 \% ;{ }^{1} \mathrm{H}-\mathrm{NMR}\left(\mathrm{CDCl}_{3}, 250 \mathrm{~Hz}\right): \delta(\mathrm{ppm})$ $2.02(\mathrm{t}, 1 \mathrm{H}, \mathrm{CH}, J=2.6 \mathrm{~Hz}), 2.48\left(\mathrm{~d}, 2 \mathrm{H}, \mathrm{CH}_{2} \mathrm{C} \equiv \mathrm{C}, J=3.77 \mathrm{~Hz}\right), 3.03(\mathrm{ls}, 1 \mathrm{H}$, $\mathrm{OH}), 3.63-3.78\left(\mathrm{~m}, 2 \mathrm{H}, \mathrm{CH}_{2} \mathrm{OH}\right), 3.82-3.90(\mathrm{~m}, 1 \mathrm{H}, \mathrm{CHN}), 5.09(\mathrm{~s}, 2 \mathrm{H}$, $\left.\mathrm{CH}_{2} \mathrm{OC}=\mathrm{O}\right), 5.43(\mathrm{~d}, 1 \mathrm{H}, \mathrm{NH}, \mathrm{J}=8.3 \mathrm{~Hz}), 7.34(\mathrm{~s}, 5 \mathrm{H}, 5 \mathrm{CH}) ;{ }^{13} \mathrm{C}-\mathrm{NMR}$ $\left(\mathrm{CDCl}_{3}, 62.9 \mathrm{~Hz}\right): \delta(\mathrm{ppm}) 21.1\left(\mathrm{CH}_{2} \mathrm{C} \equiv \mathrm{C}\right), 51.2(\mathrm{CHN}), 63.4\left(\mathrm{CH}_{2} \mathrm{OH}\right), 67.0$ $\left(\mathrm{CH}_{2} \mathrm{OC}=\mathrm{O}\right), 71.1(\mathrm{CH}), 80.1\left(\mathbf{C}_{\mathrm{q}}\right), 128.2(\mathbf{C H}), 128.3(\mathrm{CH}), 128.6(\mathrm{CH}), 136.2$ $\left(\mathbf{C}_{\mathrm{q}}\right), 156.4\left(\mathbf{C}_{\mathrm{q}}\right)$; IR $(\mathrm{NaCl}): \mathrm{v}\left(\mathrm{cm}^{-1}\right)$ 3409, 3300, 2950, 2128, 1714, 1536, 1232, 1061, 741 and 698 ; MS (ESI) : $\mathrm{m} / \mathrm{z}=256.5[\mathrm{M}+\mathrm{Na}]^{+}$; Melting point: $66-68{ }^{\circ} \mathrm{C}$.

Benzyl \{1-[5-(2,6-Dimethoxyphenyl)-1,2,4-triazin-3-yloxy]pent-4-yn2-yl\}car-bamate (12). Under nitrogen atmosphere, $n$-butyllithium (1.5 M in THF, $5.78 \mathrm{mmol}, 1.05$ eq.) was slowly added at $-78^{\circ} \mathrm{C}$ to a solution of the alcohol 11 (1.3 g, $5.5 \mathrm{mmol}, 1 \mathrm{eq}$.) in anhydrous THF (60 mL). After $40 \mathrm{~min}$ at $-78{ }^{\circ} \mathrm{C}$, a solution of triazine $1(1.98 \mathrm{~g}, 6.70 \mathrm{mmol}, 1.2 \mathrm{eq}$.) in anhydrous THF $(25 \mathrm{~mL})$ was added. The mixture was stirred for $45 \mathrm{~min}$ at $-78{ }^{\circ} \mathrm{C}$ and 1 h at $-30{ }^{\circ} \mathrm{C}$, before it was quenched at low temperature with $5 \% \mathrm{NaHCO}_{3}$. The aqueous layer was separated and extracted with AcOEt $(3 \times 100 \mathrm{~mL})$. The combined organic layers were dried with magnesium sulfate, the solvent was evaporated, and the crude product was purified by flash chromatography (PE / EtOAc, 5:5) to give compound 12 as a viscous yellow oil. Yield $88 \%$; IR $(\mathrm{NaCl}): \mathrm{v}\left(\mathrm{cm}^{-1}\right) 3298,2946,2118,1718,1599,1515,1255,1110 .{ }^{1} \mathrm{H}-\mathrm{NMR}$ $\left(\mathrm{CDCl}_{3}, 250 \mathrm{~Hz}\right): \delta(\mathrm{ppm}) 2.01(\mathrm{t}, 1 \mathrm{H}, \mathrm{HC} \equiv \mathrm{C}, J=2.6 \mathrm{~Hz}), 2.67-2.70(\mathrm{~m}, 2 \mathrm{H}$, $\left.\mathrm{CH}_{2}-\mathrm{C} \equiv \mathrm{C}\right), 3.75\left(\mathrm{~s}, 6 \mathrm{H}, \mathrm{OCH}_{3}\right), 4.28-4.37(\mathrm{~m}, 1 \mathrm{H}, \mathrm{CHNH}), 4.57-4.64(\mathrm{~m}, 1 \mathrm{H}$, $\mathrm{CH}_{2} \mathrm{CHNH}$ ), 4.76-4.82 (m, 1H, $\left.\mathrm{CH}_{2} \mathrm{CHNH}\right), 5.09\left(\mathrm{~s}, 2 \mathrm{H}, \mathrm{CH}_{2} \mathrm{OC}=0\right), 5.44(\mathrm{~d}$, $1 \mathrm{H}, \mathrm{NH}, J=8.7 \mathrm{~Hz}), 6.63(\mathrm{~d}, 2 \mathrm{H}, 2 \mathrm{CH}, J=8.5 \mathrm{~Hz}), 7.30-7.34(\mathrm{~m}, 5 \mathrm{H}, 5 \mathrm{CH})$, $7.39(\mathrm{t}, 1 \mathrm{H}, \mathrm{CH}, J=8.5 \mathrm{~Hz}), 8.96(\mathrm{~s}, 1 \mathrm{H}, \mathrm{CHC}=\mathrm{N}) .{ }^{13} \mathrm{C}-\mathrm{NMR}\left(\mathrm{CDCl}_{3}, 62.9\right.$ $\mathrm{Hz}): \delta(\mathrm{ppm}) 21.6\left(\mathrm{CH}_{2}-\mathrm{C} \equiv \mathrm{C}\right), 48.9(\mathrm{CHNH}), 56.0\left(2 \mathrm{OCH}_{3}\right), 67.0\left(\mathrm{CH}_{2} \mathrm{OC}=\mathrm{O}\right)$, $68.0\left(\mathrm{CH}_{2} \mathrm{CHNH}\right), 71.3\left(\mathrm{CH}_{2}-\mathrm{C} \equiv \mathbf{C}\right), 79.7\left(\mathrm{CH}_{2}-\mathrm{C} \equiv \mathrm{C}\right), 104.2(2 \mathrm{CH}), 112.3$ $\left(\mathbf{C}_{\mathrm{q}}\right), 128.1,128.2,128.6(5 \mathrm{CH}), 132.5(\mathbf{C H}), 136.3\left(\mathbf{C}_{\mathrm{q}}\right), 147.9(\mathbf{C H}=\mathrm{N}), 155.8$ $\left(\mathbf{C}_{\mathrm{q}}\right), 158.4\left(\mathbf{C}_{\mathrm{q}}\right), 165.0\left(\mathbf{C}_{\mathrm{q}}\right)$. IR $(\mathrm{NaCl}): \mathrm{v}\left(\mathrm{cm}^{-1}\right) 3298,2946,2118,1718,1599$, 1515, 1255, 1110; MS (ESI) : m/z = 449.5 [M+H], $471.5[\mathrm{M}+\mathrm{Na}]^{+} ; \mathrm{HRMS}$ (ESI): calcd. for $\mathrm{C}_{24} \mathrm{H}_{24} \mathrm{~N}_{4} \mathrm{O}_{5} 471.1644$, found 471.1643 .

7-(2,6-Dimethoxyphenyl)-3,4-dihydro-2H-pyrano[2,3-b]pyridin-3-amine (13). A solution of compound $12(0.5 \mathrm{~g} 1.11 \mathrm{mmol}, 1 \mathrm{eq}$.) in chlorobenzene (5 $\mathrm{mL}$ ) was heated at $220^{\circ} \mathrm{C}$ under microwaves irradiation for $1.5 \mathrm{~h}$. The solvent 
was removed in vacuo, and the residue was purified by flash chromatography (PE / EtOAc, 4:6) to afford the corresponding cycloadduc as a white solid, in a $88 \%$ yield. ${ }^{1} \mathrm{H}-\mathrm{NMR}\left(\mathrm{CDCl}_{3}, 250 \mathrm{~Hz}\right): \delta(\mathrm{ppm}) 2.84\left(\mathrm{~d}, 1 \mathrm{H}, \mathrm{CH}_{2} \mathrm{CHNH}, J=\right.$ $16.6 \mathrm{~Hz}$ ), $3.11\left(\mathrm{~d}, 1 \mathrm{H}, \mathrm{CH}_{2} \mathrm{CHNH}, J=16.6 \mathrm{~Hz}\right), 3.70\left(\mathrm{~s}, 6 \mathrm{H}, \mathrm{OCH}_{3}\right), 4.27$ (ls, $\left.3 \mathrm{H}, \mathrm{CH}_{2} \mathrm{CHNH}\right), 5.10\left(\mathrm{~s}, 2 \mathrm{H}, \mathrm{CH}_{2} \mathrm{OC}=\mathrm{O}\right), 5.39(\mathrm{~d}, 1 \mathrm{H}, \mathrm{NH}, J=6.4 \mathrm{~Hz}), 6.59$ $(\mathrm{d}, 2 \mathrm{H}, 2 \mathrm{CH}, J=8.4 \mathrm{~Hz}), 6.91(\mathrm{~d}, 1 \mathrm{H}, \mathrm{CH}, J=7.5 \mathrm{~Hz}), 7.27(\mathrm{t}, 1 \mathrm{H}, \mathrm{CH}, J=$ $8.4 \mathrm{~Hz}$ ), 7.33 (ls, $5 \mathrm{H}, 5 \mathrm{CH}), 7.41$ (d, $1 \mathrm{H}, \mathrm{CH}, \mathrm{J}=7.5 \mathrm{~Hz}) .{ }^{13} \mathrm{C}-\mathrm{NMR}\left(\mathrm{CDCl}_{3}\right.$, $62.9 \mathrm{~Hz}): \delta(\mathrm{ppm}) 31.0\left(\mathrm{CH}_{2} \mathrm{CHNH}\right), 43.7(\mathrm{CHNH}), 56.0(\mathrm{OCH} 3), 66.9$ $\left(\mathrm{CH}_{2} \mathrm{OC}=\mathrm{O}\right), 68.8\left(\mathrm{CH}_{2} \mathrm{OCHNH}\right), 104.0(2 \mathrm{CH}), 112.2\left(\mathbf{C}_{\mathrm{q}}\right), 118.4\left(\mathbf{C}_{\mathrm{q}}\right), 120.5$ $(\mathbf{C H}), 128.2(3 \mathrm{CH}), 128.6(2 \mathrm{CH}), 129.6(\mathrm{CH}), 136.3\left(\mathbf{C}_{\mathrm{q}}\right), 139.6(\mathbf{C H}), 152.0$ $\left(\mathbf{C}_{\mathrm{q}}\right), 155.8\left(\mathbf{C}_{\mathrm{q}}\right), 158.1\left(\mathbf{C}_{\mathrm{q}}\right), 159.7\left(\mathbf{C}_{\mathrm{q}}\right)$; IR $(\mathrm{ATR}-\mathrm{Ge}): \mathrm{v}\left(\mathrm{cm}^{-1}\right)$ 3338, 2942, 1715, 1602, 1472, 1248, 1111, 755; MS (ESI) : $\mathrm{m} / \mathrm{z}=421.5[\mathrm{M}+\mathrm{H}]^{+}$; HRMS (ESI): Calcd. for $\mathrm{C}_{24} \mathrm{H}_{24} \mathrm{~N}_{2} \mathrm{O}_{5} 421.1763$, found 421.1778; Melting point: 167$169^{\circ} \mathrm{C}$. To a solution of the previously obtained cycloadduct $(0.2 \mathrm{~g}, 0.5 \mathrm{mmol}$, 1 eq.) in ethanol $(10 \mathrm{~mL})$ was added $10 \% \mathrm{Pd} / \mathrm{C}(0.02 \mathrm{~g})$, and hydrogen was bubbled through the suspension for $15 \mathrm{~min}$ at room temperature. $1 \mathrm{~N} \mathrm{HCl}(0.5$ $\mathrm{mmol}$ ) was added, and the reaction mixture was stirred under hydrogen atmosphere until the complete consumption of the starting material $(10 \mathrm{~h})$. The mixture was filtered through Celite, diluted with satd. $\mathrm{K}_{2} \mathrm{CO}_{3}(25 \mathrm{~mL})$, and extracted with DCM $(3 \times 50 \mathrm{~mL})$. The separated organic layers were dried with magnesium sulfate, and the solvent was evaporated to give the amine 13 as a light yellow solid, subsequently used without further purification. Yield: $71 \%$; ${ }^{1} \mathrm{H}-\mathrm{NMR}\left(\mathrm{CDCl}_{3}\right)$ : $\delta(\mathrm{ppm}) 2.63\left(\mathrm{dd}, 1 \mathrm{H}, \mathrm{CH}_{2} \mathrm{CHNH}_{2}\right.$, $J=7.4 \mathrm{~Hz}, J=16.1 \mathrm{~Hz}$ ), $3.07\left(\mathrm{dd}, 1 \mathrm{H}, \mathrm{CH}_{2} \mathrm{CHNH}_{2}, J=5.1 \mathrm{~Hz}, J=16.1 \mathrm{~Hz}\right.$ ), 3.38-3.47 (m, 1H, $\left.\mathrm{CHNH}_{2}\right), 3.71\left(\mathrm{~s}, 6 \mathrm{H}, \mathrm{OCH}_{3}\right), 3.98\left(\mathrm{dd}, 1 \mathrm{H}, \mathrm{CH}_{2} \mathrm{O}, J=7.4\right.$ $\mathrm{Hz}, J=10.5 \mathrm{~Hz}), 4.27-4.33\left(\mathrm{~m}, 1 \mathrm{H}, \mathrm{CH}_{2} \mathrm{O}\right), 6.60(\mathrm{~d}, 2 \mathrm{H}, 2 \mathrm{CH}, J=8.4 \mathrm{~Hz})$, $6.89(\mathrm{~d}, 1 \mathrm{H}, \mathrm{CH}, J=7.5 \mathrm{~Hz}), 7.26(\mathrm{dd}, 1 \mathrm{H}, \mathrm{CH}, J=7.8 \mathrm{~Hz}, J=9.0 \mathrm{~Hz}), 7.43$ (d, $1 \mathrm{H}, \mathrm{CH}, J=7.5 \mathrm{~Hz}) \cdot{ }^{13} \mathrm{C}-\mathrm{NMR}\left(\mathrm{CDCl}_{3}\right): \delta(\mathrm{ppm}) 34.4\left(\mathrm{CH}_{2} \mathrm{CHNH}_{2}\right), 44.0$ $\left(\mathrm{CHNH}_{2}\right), 56.1\left(2 \mathrm{OCH}_{3}\right), 72.1\left(\mathrm{CH}_{2} \mathrm{O}\right), 104.1(2 \mathrm{CH}), 113.1\left(\mathbf{C}_{\mathrm{q}}\right), 118.8\left(\mathbf{C}_{\mathrm{q}}\right)$, $119.9(\mathbf{C H}), 129.5(\mathbf{C H}), 139.3(\mathbf{C H}), 151.6\left(\mathbf{C}_{\mathrm{q}}\right), 158.2\left(2 \mathbf{C}_{\mathrm{q}}\right), 160.1\left(\mathbf{C}_{\mathrm{q}}\right) ; \mathrm{IR}$ (ATR-Ge): $\vee\left(\mathrm{cm}^{-1}\right) 3358,2942,1602,1471,1248,752 ; \mathrm{MS}(\mathrm{ESI}): \mathrm{m} / \mathrm{z}=$ 287.0 [M+H] $]^{+}$; HRMS (ESI): Calcd. for $\mathrm{C}_{16} \mathrm{H}_{18} \mathrm{~N}_{2} \mathrm{O}_{3}$ 287.1396, found 287.1405.

7-(2,6-Dimethoxyphenyl)-3-(dimethylamino)-3,4-dihydro-2H-pyrano[2,3-b]-pyridine (14): To a solution of amine $13(0.08 \mathrm{~g}, 0.28 \mathrm{mmol}, 1$ eq.) in methanol $(5 \mathrm{~mL})$ was added formaldehyde $(37 \%$ aq. soln., $0.167 \mathrm{ml}, 2.32$ mmol, 8 eq.) and sodium borohydride ( $0.088 \mathrm{~g}, 1.40 \mathrm{mmol}, 5$ eq.). The $\mathrm{pH}$ of the mixture was adjusted to 6 by addition of acetic acid, and the mixture was stirred for $24 \mathrm{~h}$ at room temperature, then subsequently poured into $1 \mathrm{M} \mathrm{NaOH}$ $(10 \mathrm{~mL})$. The aqueous phase was extracted with DCM $(3 \times 30 \mathrm{~mL})$, the combined organic layers were dried with magnesium sulfate, and the solvents were evaporated in vacuo. The final compound 14 was isolated by 
flash chromatography $(\mathrm{DCM} / \mathrm{MeOH}, 95: 5)$ as a light yellow viscous oil. Yield : $70 \%$; ${ }^{1} \mathrm{H}-\mathrm{NMR}\left(\mathrm{CDCl}_{3}, 250 \mathrm{~Hz}\right): \delta(\mathrm{ppm}) 2.41\left(\mathrm{~s}, 6 \mathrm{H}, \mathrm{NCH}_{3}\right), 2.77-3.02(\mathrm{~m}$, $3 \mathrm{H}, \mathrm{CHN}, \mathrm{CH}_{2} \mathrm{CHN}$ ), 3.71 (s, $\left.6 \mathrm{H}, \mathrm{CH}_{2} \mathrm{CHN}\right), 3.99-4.09\left(\mathrm{~m}, 1 \mathrm{H}, \mathrm{CH}_{2} \mathrm{O}\right), 4.48-$ $4.54\left(\mathrm{~m}, 1 \mathrm{H}, \mathrm{CH}_{2} \mathrm{O}\right), 6.60(\mathrm{~d}, 2 \mathrm{H}, 2 \mathrm{CH}, \mathrm{J}=8.4 \mathrm{~Hz}), 6.89(\mathrm{~d}, 1 \mathrm{H}, \mathrm{CH}, J=7.5$ $\mathrm{Hz}), 7.27(\mathrm{t}, 1 \mathrm{H}, \mathrm{CH}, J=8.4), 7.45(\mathrm{~d}, 1 \mathrm{H}, \mathrm{CH}, J=7.5 \mathrm{~Hz}) ;{ }^{13} \mathrm{C}-\mathrm{NMR}\left(\mathrm{CDCl}_{3}\right.$, $62.9 \mathrm{~Hz}): \delta(\mathrm{ppm}) 29.2\left(\mathrm{CH}_{2} \mathrm{CHN}\right), 42.8\left(2 \mathrm{CH}_{3}\right), 56.0\left(2 \mathrm{OCH}_{3}\right), 57.1(\mathrm{CHN})$, $68.2\left(\mathrm{CH}_{2} \mathrm{O}\right), 104.1(2 \mathrm{CH}), 113.4\left(\mathrm{C}_{\mathrm{q}}\right), 118.8\left(\mathrm{C}_{\mathrm{q}}\right), 119.8(\mathrm{CH}), 129.5(\mathrm{CH})$, $139.1(\mathbf{C H}), 151.5\left(\mathbf{C}_{\mathrm{q}}\right), 158.2\left(\mathbf{C}_{\mathrm{q}}\right), 160.4\left(\mathbf{C}_{\mathrm{q}}\right)$; IR (ATR-Ge): $v\left(\mathrm{~cm}^{-1}\right)$ 2938, 1606, 1471, 1248, 1110, 749; MS (ESI) : $\mathrm{m} / \mathrm{z}=315.5[\mathrm{M}+\mathrm{H}]^{+}$; HRMS (ESI): Calcd. for $\mathrm{C}_{18} \mathrm{H}_{22} \mathrm{~N}_{2} \mathrm{O}_{3} 315.1471$, found 315.1460

\section{REFERENCES}

1. E. Badarau, F. Suzenet, A.L. Fînaru, G. Guillaumet, European Journal of Organic Chemistry, 2009, 21, 3619.

2. P. Holmberg, D. Sohn, R. Leideborg, P. Caldirola, P. Zlatoidsky, S. Hanson, N. Mohell, S. Rosqvist, G. Nordvall, A.M. Johansson, R. Johansson., Journal of Medicinal Chemistry, 2004, 47, 3927.

3. T.W. Butler, T.T. Wager, International Patent WO2007/088450, 9 Aug 2007

4. P. Garner, J.M. Park, Journal of Organic Chemistry, 1987, 52, 2361.

5. D.R. Hou, J.H. Reibenspies, K. Burgess, Journal of Organic Chemistry, 2001, 66, 206.

6. G.M. Ksander, R. de Jesus, A. Yuan, R.D. Ghai, A. Trapani, C. McMartin, R. Bohacek, Journal of Medicinal Chemistry, 1997, 40, 495.

7. E.J. Corey, P.L. Fuchs, Tetrahedron Letters, 1972, 13, 3769. 